\title{
Cenomanian - Turonian transition in the Cretaceous of southern India
}

\author{
K.AYYASAMI AND RANJIT K. BANERJI
}

\begin{abstract}
Ayyasami, K. \& Banerji, Ranjit K.: Cenomanian - Turonian transition in the Cretaceous of southern India. Bull. geol. Soc. Denmark, vol. 33 pp. 21-30, Copenhagen, September, 10 th, 1984. https://doi.org/10.37570/bgsd-1984-33-02

The Cretaceous formations of southern India range from Upper Albian to Maastrichtian in age on the basis of their macro- and microfauna. A considerable number of faunal elements are either identical or closely related to forms known from the European Cretaceous, and a precise correlation between the two areas is possible. In this paper the contact between the Cenomanian and Turonian in southern India is reviewed. Rocks of the Upper Cenomanian age consist of medium to coarse grained calcareous sandsto-nes and limestone bands, frequently crowded with fossils. They are interbedded with brown shales. These are overlain by Turonian limestone full of Exogyra, in turn overlain by fossiliferous calcareous concretions embedded in brown shales. Lower Turonian beds may overlap the uppermost Cenomanian in the northern part of the study area. The uppermost Cenomanian yielded Eucalycoceras pentagonum and Pseudocalyco-ceras harpex associated with Inoceramus pictus. The Lower Turonian yields Pseudaspidoceras conciliatum, Neoptychites cephalotus and Mytiloides mytiloides. Foraminifera are rare in the Turonian succession.
\end{abstract}

K. Ayyasami, 5-5-449, Mukram Jahi Road, Hyderabad-500001, India. Ranjit K. Banerji, Department of Earth Sciences, Indian Institute of Technologg, Bombay-400076, India. March 4th, 1984.

\section{Introduction}

The Cretaceous formations of southern India occur in a series of isolated outcrops in the Tiruchirappalli district, Tanjore and Vridhackallam i Tamil Nadu (formerly Madras state) and in Pondicherry separated by younger sediments. The outcrops in the Tiruchirappalli district are the largest and are dated as Middle Albian to Maastrichtian, whereas the rocks of the other three outcrop areas are dated as Campanian to Maastrichtian in age. The present study of the Cenomanian - Turonian boundary in southern India is thus limited to outcrops in the Tiruchirappalli district (Fig. 1).

\section{Lithostratigraphy}

The present work is confined to the upper beds of the Uttattur Group (Ootatoor group) as defined by Blanford (1862) who gave a detailed account of lithological variations in this group. Indeed, Blanford's observations on the upper beds of the Uttattur Group (1862, p. 93) form the basis of our study.

The topography of the area is much dissected with the shell limestones forming high ground and the streams of the area have their source among these. The stream discharge is seasonal and the long dry season affords easy extraction of the fauna. However, as Blanford earlier observed, the separation of fossils from nodules is very difficult.

In the exposed sections, the beds dip approximately $8^{\circ}$ due east. The description of the lithology along the stream sections are as follows:

Stream section north of Adanur village

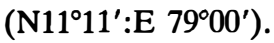

This section exposes the rock of the upper Uttattur beds for a distance of about half a mile. Many Lower Turonian fossils were collected from the limestone nodules in the shale unit from this stream which is being brought under dry crop cultivation. The lower reaches of the stream are concealed under arable lands, though in places, unfossiliferous calcareous sandstones are seen in dug well debris and thus other lithological units are not available for correlation.

Stream section due east of Odiyam village.

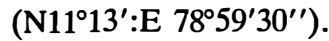

Thiis section is one of the best developed and 


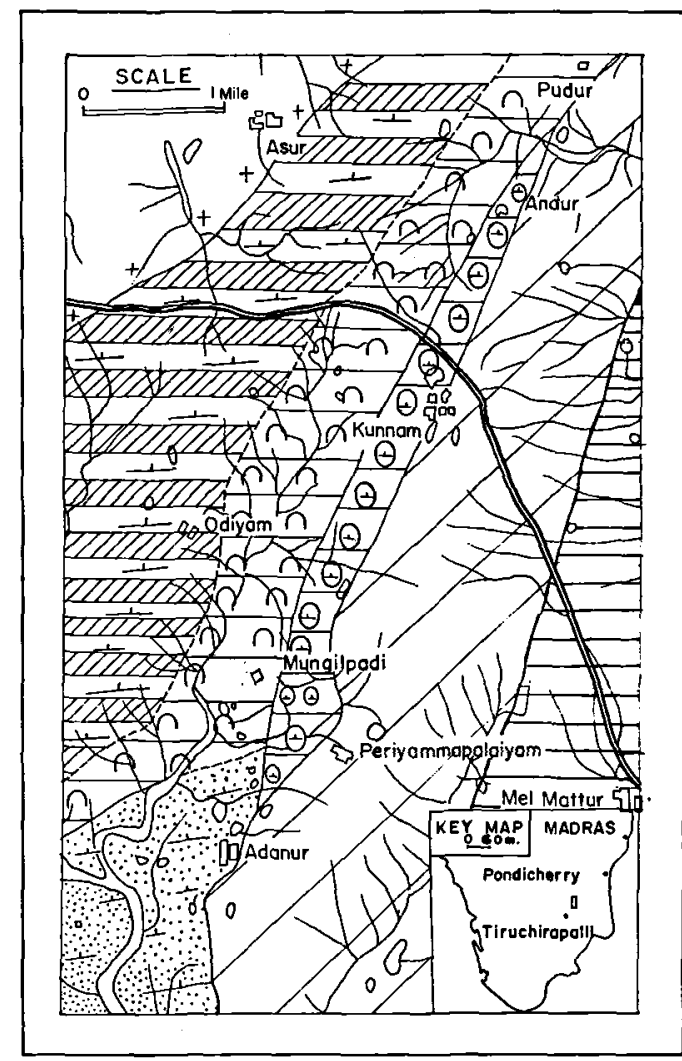

Cenomonian-Turonian transition beds in the Cretaceous of southern Indio

(Tiruchiropolli District outcrop area)

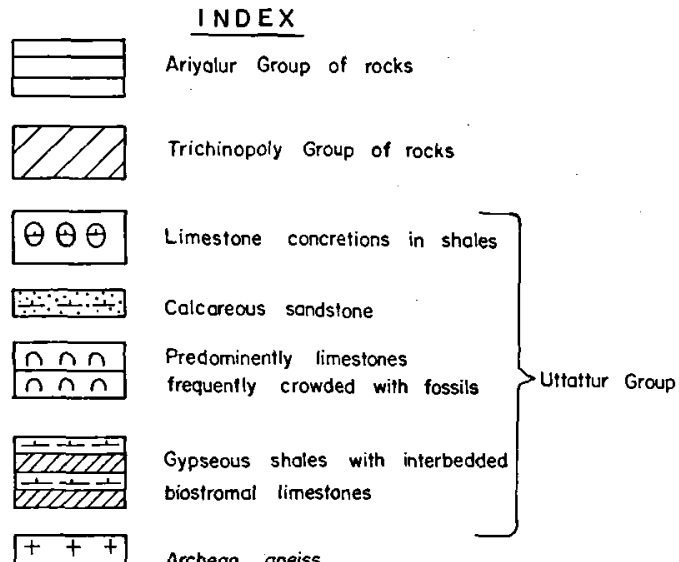

+++ Archean gneiss

Fig. 1: Map showing the lithological units at the Cenomanian-Turonian contact in southern India.

the rocks are exposed for nearly a mile. Numerous fossils were collected from this locality. Hence, it is designated as the type section. The stratigraphic column prepared along this section is shown in Fig. 4.

At the confluence of this tributary stream and the main stream flowing southwards to the west of it, the shell limestones with numerous molluscan fossils are exposed followed by limestone nodules in a gypseous clay unit. Further upstream, the shell limestones with numerous bivalve Exogyra suborbiculata (Stoliczka) cross the stream. From then on, shell limestones and limestone nodules in shales almost alternate for a short distance. The strike extension of these units may be explorable in the still smaller tributaries flowing into this stream from north and south directions. Non-gypseous whitish shale, forming the uppermost unit of the Uttattur Group, are exposed at the source of the stream, and are immediately overlain by shell limestones of the Trichinopoly Group.
Stream section southwest of Kunnam village.

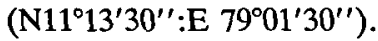

At the confluence of the small stream flowing west and joining the main stream southwest of Kunnam village, the limestone with numerous Inoceramus pictus (Woods) is exposed. This limestone is overlain by shales with limestone nodules. The traverse upstream leads to two bands of shell limestone with abundant Exogyra suborbiculata (Stoliczka) intercalated by shales of about $3 \mathrm{~m}$. Overlying the second band of limestone are the shales with limestone nodules yielding Pseudaspidoceras footeanum (Stoliczka). The whitish shales form the next overlying lithological unit, in turn overlain by the basal shell limestones of the Trichinopoly Group.

Stream section west of Andur village. (N11 $15^{\circ}$ : E $\left.79^{\circ} 01^{\prime} 30^{\prime \prime}\right)$.

The stream flowing northwards and its small tributaries west of Andur village is one of the best 


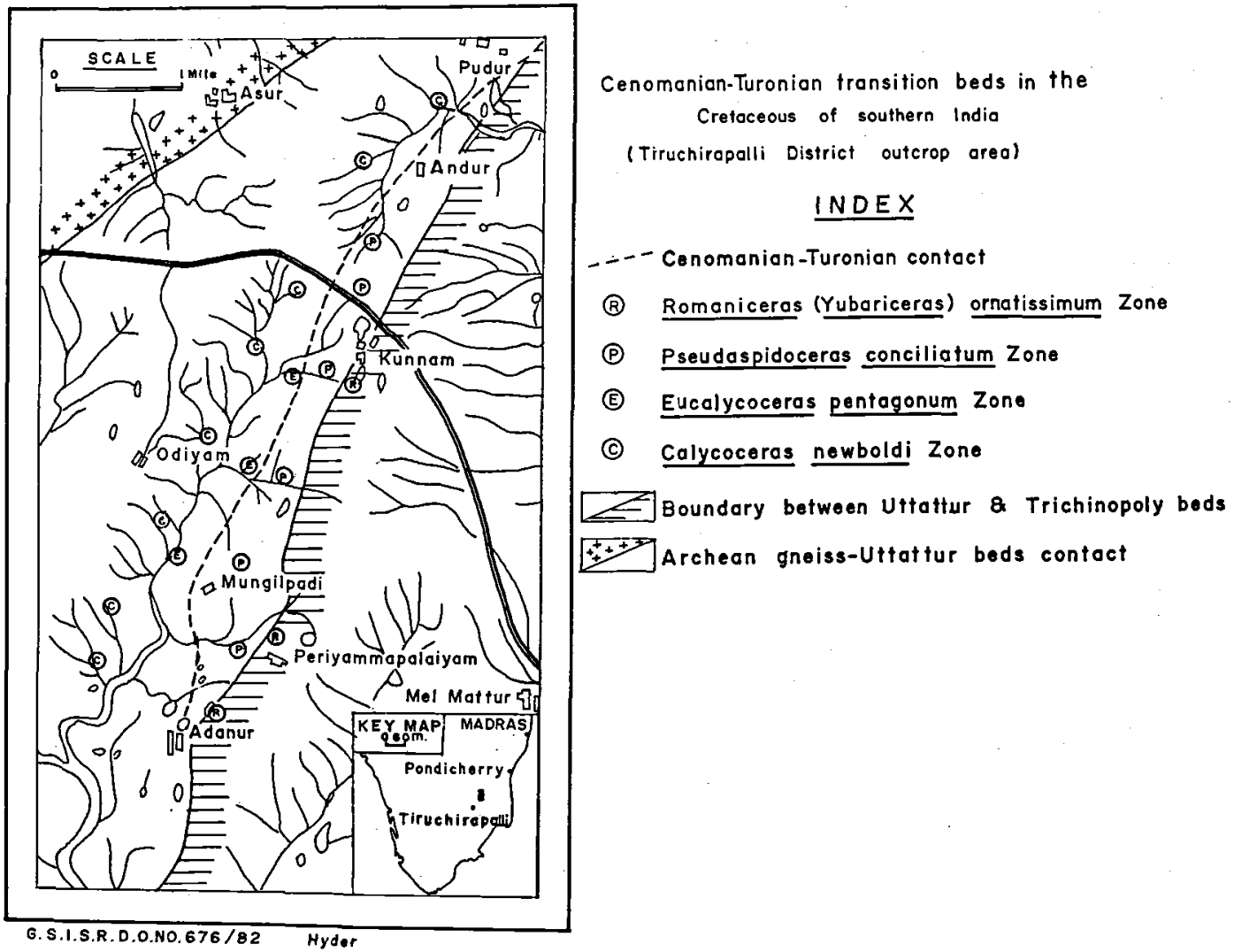

Fig. 2: Map showing the proposed biostratigraphic zones at the Cenomanian-Turonian contact on the toposheet.

localities for fossil collection, as its course coincides with the general strike of the beds. A few limestone bands yielding Calycoceras newboldi planicostatum (Kossmat) and Calycoceras stoliczkai (Collignon) are seen directly overlain by fossiliferous shell limestones yielding Exogyra suborbiculata (Stoliczka) shells. They are succeeded by a litho-unit of limestone nodules in shales. Numerous specimens of the giant ammonites Pachydesmoceras denisonianum (Stoliczka) and P. pachydiscoide (Matsumoto) were collected. The shell limestones of the Tri- chinopoly Group (?) are visible where the stream turns abruptly eastward, north of Andur village.

\section{Biostratigraphy}

There is a striking correspondence between lithological boundaries and the biostratigraphic zones proposed here (Fig. 2). The biozonation is based on ammonoids, which are abundant and well preserved. Foraminifera, brachipods, corals, and echinoderms are rare, at least in the early Turonian rocks. The biostratigraphic scheme is as follows:

\section{European stage Ammonite biostratigraphic zones}

\begin{tabular}{ll}
\hline Lower Turonian & Pseudaspidoceras conciliatum Zone \\
Upper Cenomanian & Eucalycoceras pentagonum Zone \\
Middle Cenomanian & Calycoceras newboldi Zone
\end{tabular}




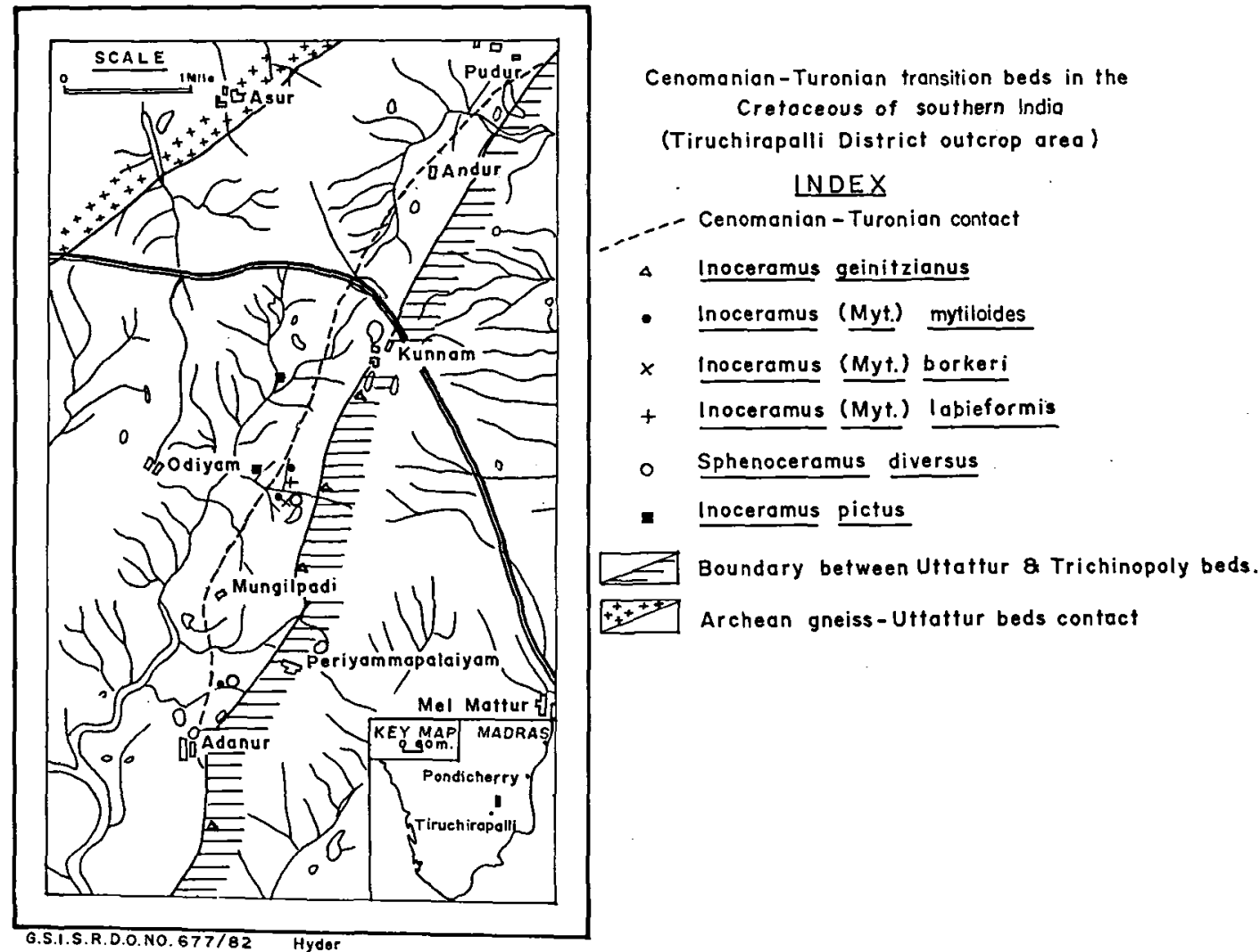

Fig. 3: Map showing the localities yielding species of inoceramids at the Cenomanian-Turonian contact.

The Calycoceras newboldi Zone is one of the best developed units in the southern Indian Cretaceous and has yielded this index fossil consistently along the strike from near Siruganur (N 11.01': E $\left.78^{\circ} 47^{\prime} 30^{\prime \prime}\right)$ to the south of Paravay (N $11^{\circ} 17^{\prime}$ : E $\left.79^{\circ} 02^{\prime} 30^{\prime \prime}\right)$. In contrast, the $E u$ calycoceras pentagonum Zone is limited to the northern part of the area. The extension to the southern part of the Cretaceous basin is dependent entirely on inferences based on field lithostratigraphic observations as no ammonoids are collected beyond Mungilpadi village ( $\mathrm{N}$ $11^{\circ} 12^{\prime}$ : E $\left.79^{\circ} 00^{\prime} 30^{\prime \prime}\right)$. Further discussion of the extension of this zone is dealt with subsequently in the stratigraphic notes on Inoceramus multiplicatus (Stoliczka). A Pseudaspidoceras conciliatum Zone was proposed by Kossmat (1895-98) and used by Sastry, Rao \& Mamgain (1968) and Chiplonkar \& Phansalkar (1976). We adopt this zone with minor modifications (see Table 1 and 2). The strike extension of this zone is limited to the northern part of the Cretaceous outcrop area (Fig. 2). Foraminiferal evidence by Narayanan (1977), however, presents a different picture as will be discussed later.

Remarks on previous zonations at the Cenomanian - Turonian contact.

Kossmat (1895-98) was the first to propose a biostratigraphic zonation for the Upper Cretaceous sediments of southern India. He showed beds with Acanthoceras cf. rhotomagense overlain by those yielding Pseudaspidoceras conciliatum at the contact of Cenomanian and Turonian Stages, and clearly demonstrated the presence of a part of the Turonian Stage in the Uttattur Group. However, there is a fossiliferous horizon yielding Eucalycoceras pentagonum (JukesBrowne \& Hill) and Pseudocalycoceras harpax (Stoliczka) between the 'Acanthoceras' beds and beds with Pseudaspidoceras conciliatum 
TABLE SHOWING THE DISTRIBUTION OF AMMONOID SPECIES

AT THE CENOMANIAN - TURONIAN CONTACT IN SOUTHERN INDIA

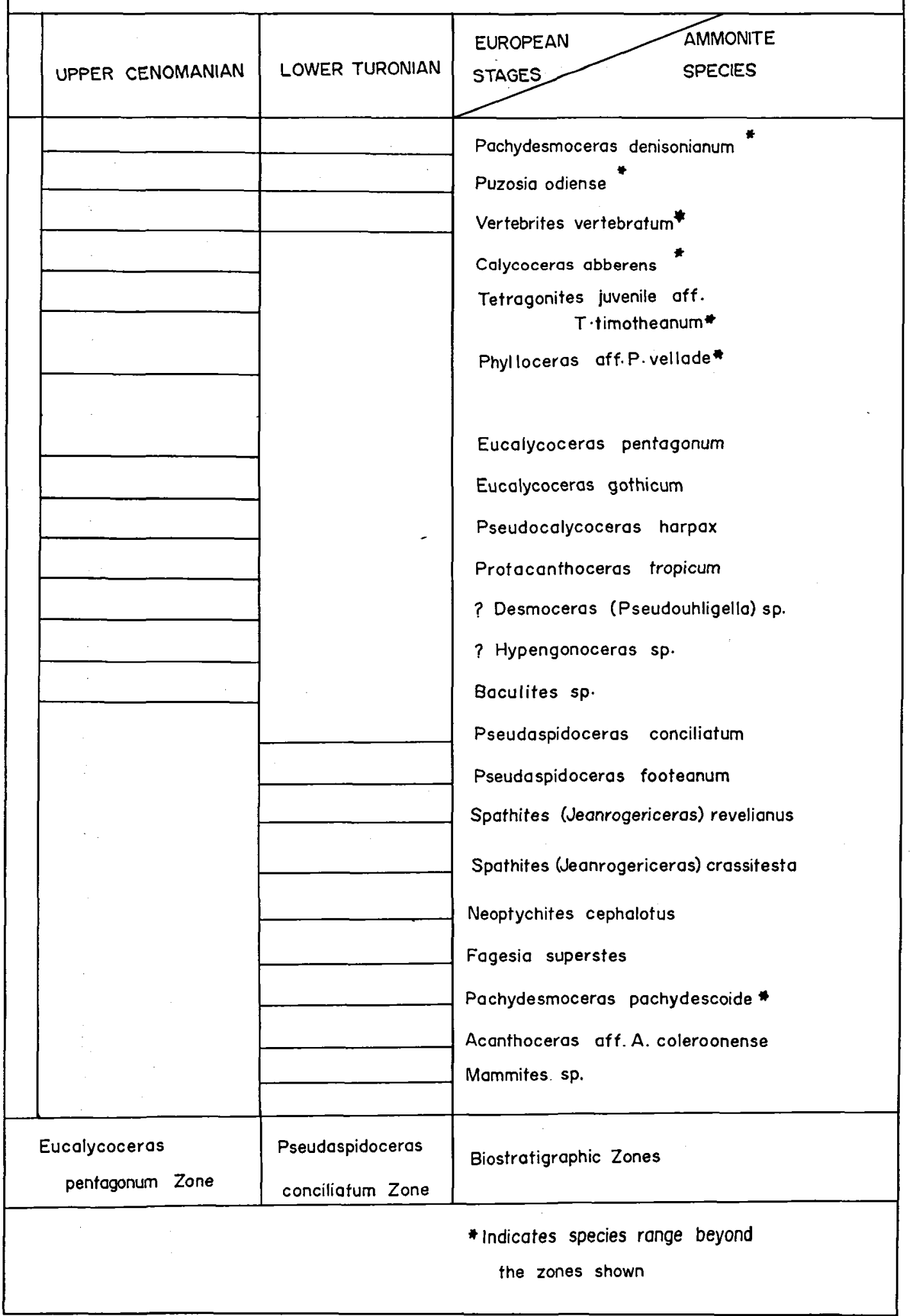


TABLE SHOWING THE DISTRIBUTION OF INVERTEBRATE FOSSILS AT ' THE CENOMANIAN - TURONIAN CONTACT IN SOUTHERN INDIA

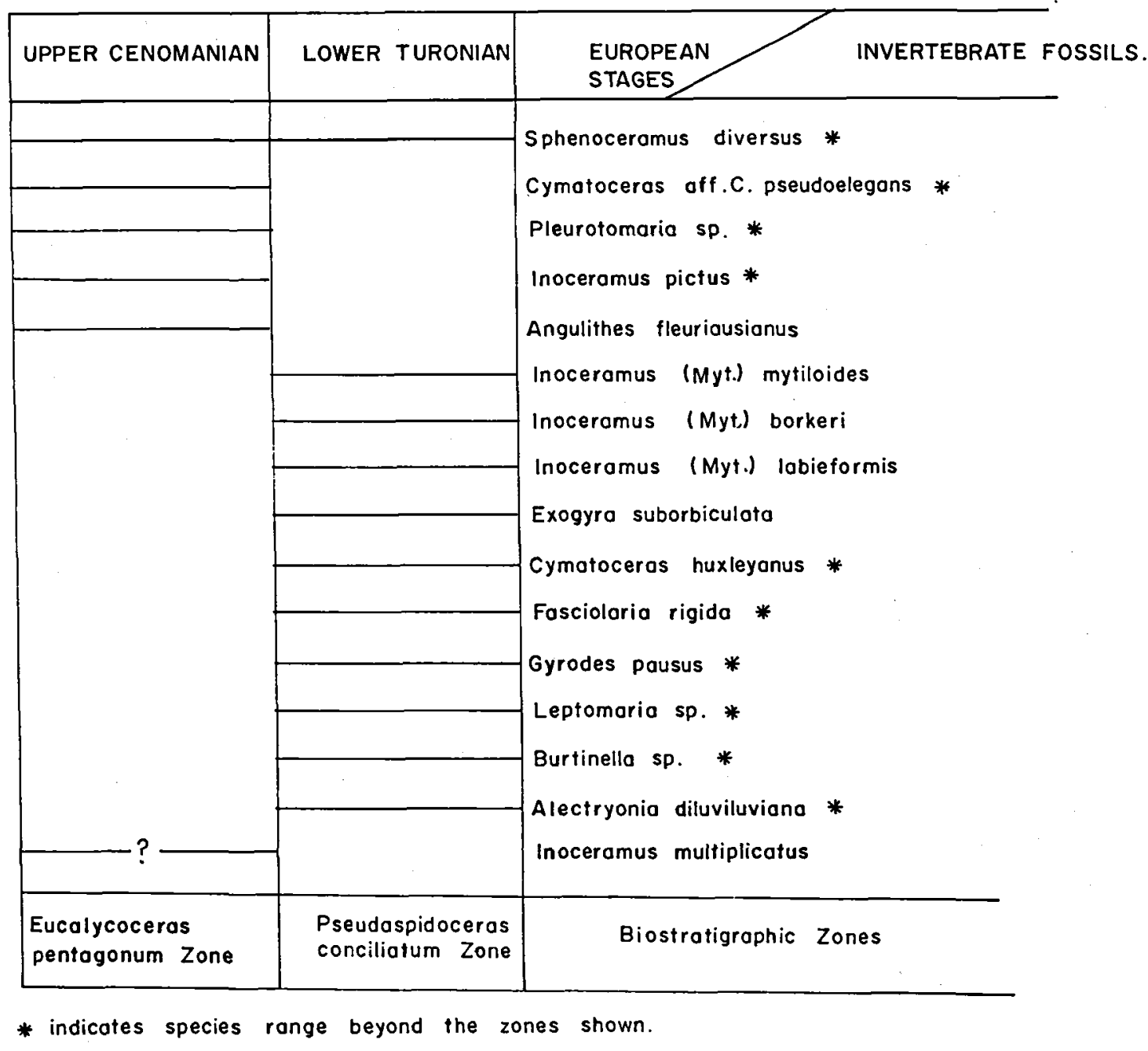

Table 2.

(Stoliczka) at Kunnam. However, as mentioned earlier the Upper Cenomanian horizon with $E u$ calycoceras pentagonum (Jukes-Browne \& Mill) is absent northwards, being overlapped by the early Turonian rocks.

Sastry et al. (1968) followed Kossmat's zonation for the Uttattur Group. The associated fossils described by them in the early Turonian horizon included Turrilites costatus (Lamarck). It is unfortunate that there had been a confusion of their illustrations, as Mariella (Mariella) bergeri (Brongniart) (refer Sastry et al. 1968, pl. 1, fig. 4) is presented as Turrilites costatus (Lamarck). Further, all their photographs illustrate type fossils described by Stoliczka (1866). Therefore, we are unable to assess the validity of this evidence of the presence of $T$. costatus (Lamarck) in the early Turonian rocks as indicated by them. We note that in our own collections Turrilites costatus (Lamarck) is confined to Calycoceras newboldi Zone, i.e., the Middle Cenomanian, and that costatus is restricted to the Middle and Upper Cenomanian elsewhere (Europe, Africa, etc.).

Chiplonkar \& Phansalkar (1976) suggested Ca- 
lycoceras choffati and Mammites conciliatum Zones at the contact of the Cenomanian and Turonian stages in southern India. However, a Calycoceras choffati (Kossmat) in the collections of University of Poona (Type no. Kn 10a) occurs in association with Calycoceras newboldi planicostatum (Kossmat) in the same limestone block. Matsumoto, Saito \& Fukada (1957, p. 37) also indicated the occurrence of Calycoceras newboldi (Kossmat) with C. choffati (Kossmat). As such, the proposal of a Calycoceras choffati Zone cannot be supported.

Chiplonkar \& Phansalkar (1976) reported Kanabiceras septemseriatum from the Trichinopoly Group. On studying the specimen (MACS type no. 526) at the MACS Research Institute, Pune, it is observed that it is a small, immature, poorly preserved, closely ribbed individual assignable to Romaniceras deverianum (d'Orbigny). At no stage of its growth does it show the multiplication of tubercles on the siphonal line that characterises Kanabiceras septemseriatum (Cragin).

Numerous inoceramids were recorded by Chiplonkar \& Tapaswi (1974) and a biostratigraphic zonation was also proposed by the same authors based on this group (Chiplonkar \& Tapaswi, 1975). An Inoceramus labiatus and $I$. inequivalvis assemblage Zone spanned the upper part of the Uttattur Group and was referred to the Upper Cenomanian to Lower Turonian. The specimen of 1 . labiatus of Chiplonkar \& Tapaswi (1974) (MACS type no. 396) should be assigned to Mytiloides mytiloides (Mantell) following the definition of Kauffman, Hattin \& Powell (1977). Fig. 3 shows the localities of some of the inoceramid species of the upper Uttattur beds.

Stratigraphic position of Inoceramus multiplicatus (Stoliczka)

Inoceramus multiplicatus (Stoliczka) is one of the most abundant fossils of the Uttattur Group. It occurs in argillaceous limestones west of Garudamangalam (N $11^{\circ} 05^{\prime}$ : E $78^{\circ} 55^{\prime}$ ) and Anaipadi (N $11^{\circ} 06^{\prime}$ : E $78^{\circ} 56^{\prime}$ ) and in calcareous sandstones associated with Acteonella sp. (Kossmat, 1895, p. 6) to the north of Kulakkalnattum (not shown in the maps presented here). These rocks are assigned a Cenomanian age by Sastry $\&$ Sastri
(1966) based on foraminifera. Stratigraphically, the shell limestones of the Trichinopoly Group overlies these beds at all the said localities.

Narayanan (1977) recorded Lower Turonian foraminifera probably from this horizon. He reported Heterohelix globulosa (Ehrenberg), Guembelitria harrisi (Tappan), Hedbergella bornholmensis (Douglas \& Rankin), Globigerinelloides caseyi (Bolli, Loeblich \& Tappan), Clavihedbergella simplex (Morrow), Marginotruncana indica (Jacob \& Sastry), Hedbergella amabilis (Loeblich \& Tappan), Heterohelix moremani (Cushman), Praeglobotruncana stephani (Gandolfi), Marginotruncana difformis (Gandolfi), M. sigali (Reichel), $M$. helvetica (Bolli) and $M$. renzi (Gandolfi). However, foraminifera are absent in the shales of the early Turonian rocks yielding ammonites (Sastry \& Sastri, 1966). Our efforts to collect foraminifera from similar horizons near Kunnam are not successful so far.

\section{Remarks on species of Romaniceras}

The genus Romaniceras is represented by two species in the southern Indian Cretaceous, namely, Romaniceras deverianum (=Ammonites medlicottianus) (Stoliczka) and Romaniceras (Yubariceras) ornatissimum (Stoliczka). Both were erroneously reported from the Uttattur Group earlier. However, our present collections clearly indicate that the two species belong to the Trichinopoly Group. A detailed discussion on the occurrence of Romaniceras species in southern India is presented in a separate paper (Ayyasami \& Rao, 1984, in press).

Fossils at the Cenomanian - Turonian contact in southern India and Europe

It is observed that a number of our fossils are common to southern India and Europe. The fossils Eucalycoceras pentagonum (Jukes-Browne \& Hill), E. gothicum (Kossmat), Inoceramus pictus (Woods), Neoptychites cephalotus (Courtiller), Fagesia superstes (Kossmat), Spathites (Jeanrogericeras) reveliereanus (Courtiller) and Mytiloides mytiloides (Mantell). The southern Indian forms which have close allies in the European Cretaceous are Protacanthoceras tropicum (Stoliczka), Pseudaspidoceras footeanum (Stoliczka), 

ornatissimum Zone

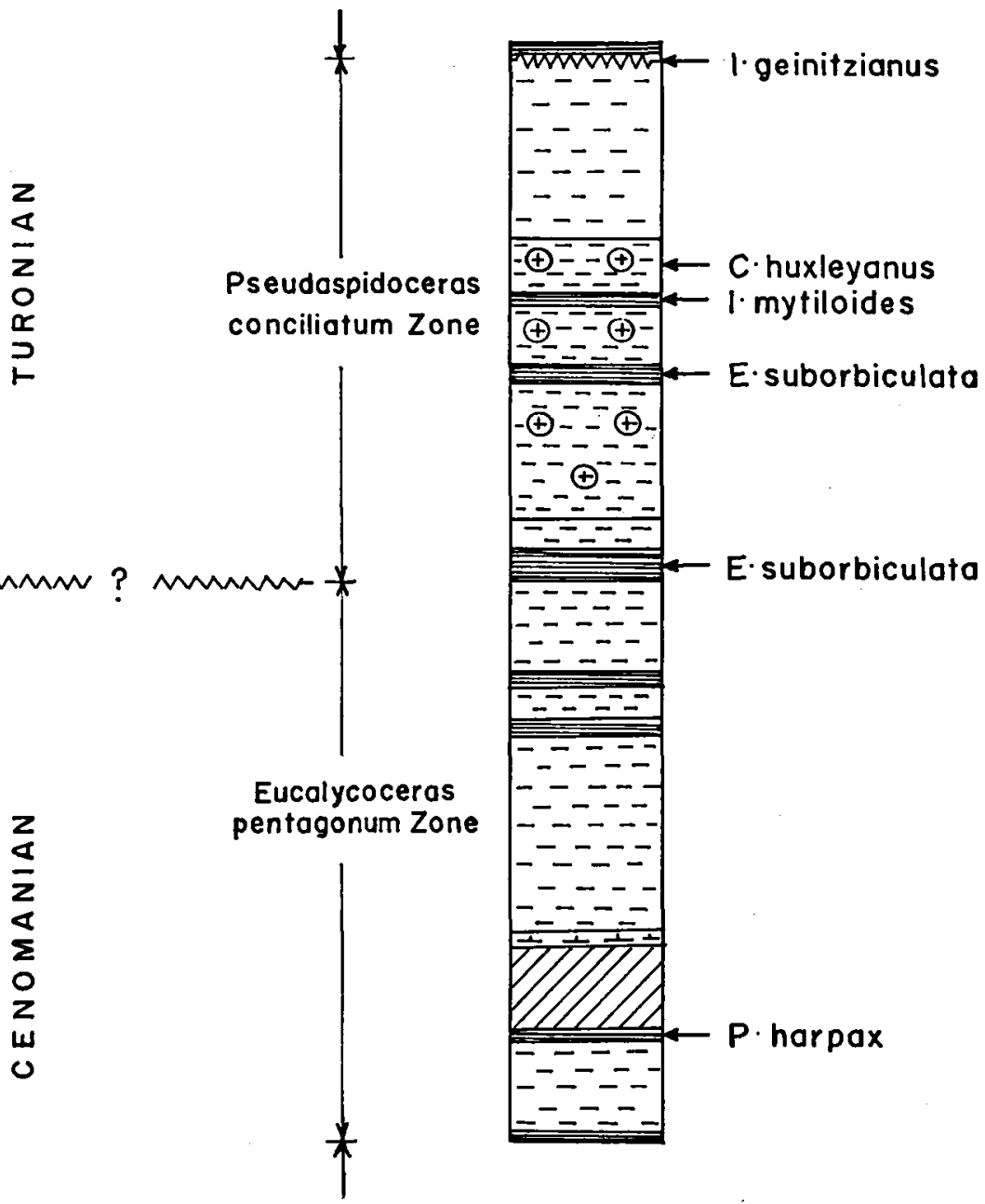

Non-gypseous shales with limestone nodules

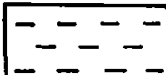

Non-gypseous shales types along the stream section due east of

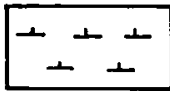

Limestone

Gypseous shales with limestone nodules

Shell limestone. 
Biostratigraphic

zones in southern

European stages

India

Romaniceras

(Yubariceras)

Middle Turonian

ornatissimum Zone

(part)

Lacuna

Pseudaspidoceras

consiziatum zone

Lower Turonian

Lacuna

Eucalycoceras

pentagonum Zone

Upper Cenomanian

Calycoceras

newboldi zone

Midßle Cenomanian

Table 3: Table showing the correlation of biostratigraphic zones of southern India with European stages.

and Spathites (Jeanrogericeras) crassitesta (Stoliczka). Fagasia rudra (Stoliczka) is not represented in our collection.

\section{Conclusions}

Based on the above discussions on invertebrate fossils, faunal succession and lithostratigraphy, the following conclusions are made.

1. The uppermost Cenomanian in southern India yields Eucalycoceras pentagonum (JukesBrowne \& Hill) and associated fossils.

2. Beds with Vascoceras gamai and other species of the genus Vascoceras are not represented in the southern Indian Cretaceous. This horizon is either not developed in southern India or is overlapped by younger rocks, the former being more probable. It is not yet clear whether this horizon is equivalent to rocks yielding Inoceramus multiplicatus (Stoliczka) in the southern part of the basin beyond the Marudayar river, where Turonian foraminifera were previously reported (Narayanan, 1977).

3. The earliest Turonian rocks are those yielding Exogyra suborbiculata (Stoliczka) and they are succeeded by rocks with numerous spathitids and vascoceratids.

4. We record the association of Neoptychites cephalotus (Courtiller), Fagesia superstes (Kossmat), Spathites (Jeanrogericeras) reveliereanus (Courtiller), S. (J) crassitesta (Stoliczka) and My- 
tiloides mytiloides (Mantell) in limestone nodules in shales exposed in the stream section to the north of Adanur village.

5. The multituberculate euomphaloceratid, Romaniceras kallasi (Zazvorka) is not represented in southern India and this horizon is most probably not developed here.

6. The succession of Romaniceras seen in the Turonian of Europe (barring Romaniceras kallasi (Zazvorka)) is present in India also (see Kennedy et al. 1980 and Ayyasami \& Rao, 1984, in press).

7. Table 3 shows the correlation of the biostratigraphic zones in southern India with European stages.

Acknowledgements. We thank the Director, Indian Institute of Technology, Bombay, India for the laboratory facilities. Mr. M. V. A. Sastry, former Director and Mr. B. R. J. Rao, Director, Geological Survey of India made available for consultation numerous reprints on Cretaceous rocks. Professor G. W. Chiplonkar and co-workers of MACS Research Institute, Pune, India aided us in the study of the invertebrate type collections from southern Indian Cretaceous preserved in their institute. We acknowledge the help rendered by Mr. T. C. Rai, Translator (German), GSI, Calcutta for translating Dr. Kossmat's volume (1895-98) into English.

\section{Dansk sammendrag}

Aflejringer fra øvre albien til maastrichtien i Sydindien indeholder mange europæiske faunaelementer og kan derfor ret præcist korreleres med Europas kridttidsaflejringer. Cenomanien - turonien grænselagene beskrives i detaljer og den stratigrafiske udbredelse af ammoniter og inoceramer omkring denne grænse analyseres. I den øverste del af cenomanien forekommer Eucalycoceras pentagonum og Pseudocalycoceras harpex sammen med Inoceramus pictus. Nedre turonien karakteriseres af Pseudaspidoceras conciliatum, Neoptychites cephalotus og Mytiloides mytiloides.

\section{References}

Ayyasami, K. and Rao, B. R. J. 1984: Observations on the biostratigraphic zones of the Trichinopoly Group (Upper Cretaceous), Tamil Nadu. $X$ Indian colloquium on Micropalaeontology and stratigraphy, Pune. (in press).

Blanford, H. F. 1862: On the Cretaceous and other rocks of South Arcot and Trichinopoly districts, Madras. Memoir of the Geological Survey of India, I, part iv.

Chiplonkar, G. W. and Phansalkar, V. G. 1976: Comments on the biostratigraphy of the Upper Cretaceous rocks of South India. Proceedings of the IV Indian colloquium on Micropalaeontology and stratigraphy, Banaras, 26-32.

Chiplonkar, G. W. and Tapaswi, P. M. 1974: Bivalvia from the Upper Cretaceous of Trichinopoly district, South India. Part I - Inoceramidae. Recent Researches in Geology, Chandigarh, 3, 87-123.

Chiplenkar, G. W. and Tapaswi, P. M. 1975: Biostratigraphy of the Inoceramids in the Upper Cretaceous of Trichinopoly district, South India. Biovigyanam,1, 11-15.

Kauffman, E. G., Hattin, D. E. and Powell, J. D. 1977: Stratigraphic, palaeontologic, and palaeoenvironmental analysis of the Upper Cretaceous rocks of Cimarron County, Northwestern Oklahoma. Memoirs of the Geological Society of America, 149, 1-150, pls. 1-12.

Kennedy, W. J., Wright, C. W. and Hancock, J. M. 1980: The European species of the Cretaceous ammonite Romaniceras with a revision of the genus. Palaeontology, 23, 325-362.

Kossmat, F. 1895-98: Untersuchungen uber die südindische Kreideformation. Beitrage zur Geologie und Palaeontologie Osterreich - Ungarns und des Orients. Bd. 9,11 and 12.

Matsumoto, T., Saito, R. and Fukada, A. 1957: Some acanthoceratids from Hokkaido. Memoir of the Faculty of Science, Kyushu University, ser. D, 6, 1-45, pls. 1-18.

Narayanan, V. 1977: Biozonation of the Uttatur Group, Trichinopoly, Cauvary basin. Journal of the Geological Society of India, 18, 415-428.

Sastry, M. V. A., Rao, B. R. J. and Mamgain, V. D. 1968: Biostratigraphic zonation of the Upper Cretaceous Formation of Trichinopoly district, South India. Memoir of the Geological Society of India, 2, 10-17.

Sastry, M. V. A. and Sastri, V. V. 1966: Foraminifera from the Utatur stage of the Cretaceous formations of Trichinopoly district, Madras. Records of the Geological Survey of India, 94, 277-296.

Stoliczka, F. 1866: Cretaceous fauna of southern India. Cephalopoda. Memoir of the Geological Survey of India. Palaeontologia Indica. sec. 2. 